\title{
20. GADSIMTA VĒSTURISKĀS PAAUDZES UN TO IDENTIFIKĀCIJA LATVIJAS IEDZĪVOTĀJU DZİVESSTĀSTOS
}
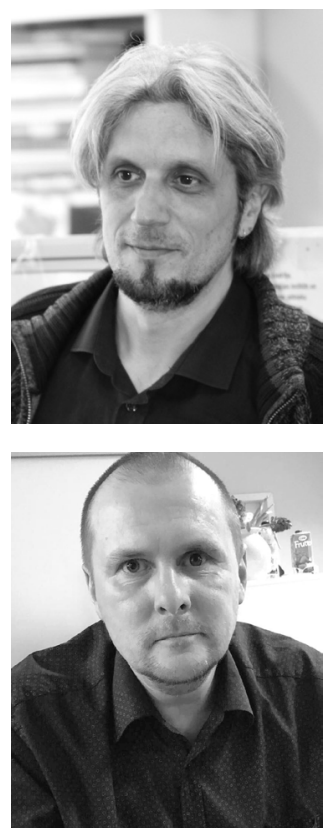

Edmunds Šūpulis (1974) studējis Latvijas Universitātes Vēstures un filozofijas fakultātē, ieguvis maǵistra grādu socioloǵijā (1999). Strādā par pētnieku LU Filozofijas un sociologiijas institūtā, tostarp Nacionālās mutvārdu vēstures projektā, līdzdarbojies valsts pētījumu programmā Letonika. Kopš 2018. gada veic izpēti FLPP projektā par paaudžu atmiņas pārnesi. Zinātnisko interešu lokā ir kolektīvās atmiņas teorija un atmiņas politika, mutvārdu vēstures izpētes metodoloǵija, identitāšu problemātika.

Kaspars Zellis (1972) ir vadošais pētnieks LU Filozofijas un socioloǵijas institūtā, Nacionālās mutvārdu vēstures projektā. Ieguvis vēstures doktora grādu LU (2011). Sarakstījis monogrāfiju Ilūziju un bailu mašinērija. Propaganda nacistu okupētajā Latvijā: vara, mediji un sabiedrība (1941-1945) (2012). Pētnieciskās intereses saistītas ar sociālo un kultūras vēsturi, ikdienas dzīves vēsturi, propagandas izpēti, kolektīvo atminu.

Raksturvārdi: paaudzes, kohorta, vēsturiskā pieredze, atmiņa, dzīvesstāsti.

\section{Ievads}

Lai gan dzīvojam vienā laikā, tomēr visi neesam vienaudži, un tas nozīmēe, ka sabiedrībā paralēli pastāv dažādas vēsturiskās pieredzes, ko iemieso atšksirīgu paaudžu pārstāvji. Tādēḷ var atšķirties arī vērtības, attieksmes un rīcības modeḷi. Cilvēku uzvedība, nostādnes mainās dz̄̄ves laikā, mums pieaugot, kḷūstot vecākiem - laikā, kad no demogrāfijas viedokḷa pārvietojamies no vienas vecumgrupas citā. Bet vienā punktā mēs paliekam allaž nekustīgi - allaž piederīgi savai paaudzei. Vai paaudzes jēdziens ir viennozīmīgi saprotams un vai pašas paaudzes ir skaidri saskatāmas konkrētā sabiedrībā, - šos jautājumus esam likuši raksta pamatā.

Sociālo zinātṇu literatūrā, analizējot sabiedrības struktūru, starp tādiem faktoriem kā dzimte, vecums, šķiriskā un etniskā piederība paaudzei ir îpašs statuss. Paaudzes nodrošina dzīves reprodukciju, sociālās informācijas translāciju un vienlaicīgi stabilu ilgstamību ar potenciālu izmainu ienešanu. Pētnieki cenšas atbildēt, kā vēsturiski veidojas paaudzes un kas, iznemot līdzīgus dzimšanas gadus, apvieno statistiski nodalītās cilvēku kohortas, veicina vai kavē to identitāti un sociālās ietekmes spēju. Rakstā aplūkosim paaudžu fenomena 
izpratni, kā tas veidojies 20. gadsimtā, akcentējot paaudzes kā unikālas lokalizācijas sociāli vēsturiskajā laikā, nošķirot tās no ikdienas izpratnes par paaudzēm kā biologiskiem atražošanas cikliem, kad tiek runāts par bērniem un vecākiem jeb "jaunāko/vecāko paaudzi”. Paaudžu analīzē ir veidojušās vairākas pieejas, kas tiek lietotas atkarībā no sociālo zinātņu jomas un pētnieciskā fokusa, - ko pētnieki grib panākt un kam pievērst uzmanību, lietojot paaudžu jēdzienu. Paaudzes jēdziens var būt loti ietilpīgs, un to ir pamanījuši paši pētnieki, uzsverot, ka tas apzīmē vairākas realitātes esamības bioloǵisko realitāti, dzīves vēsturisko realitāti, kā arī zināšanu nodošanas epistemoloǵisko problēmu ${ }^{1}$. Šīs daudzās nozīmes bieži darbojas vienlaicīgi un sniedz nozīmīgu skaidrojumu sociālās pasaules izpratnē. Cik lielā mērā paaudžu jēdziena dažādās interpretācijas un modeḷus akadēmiskajā literatūrā var attiecināt uz mūsu sabiedrību, par to diskutējam šajā rakstā.

Daudzās vēsturiskās transformācijas Latvijā ir ietekmējušas paaudžu dinamiku, to formēšanos un pašapziņu. Līdztekus tam arī katra paaudze veido savu atmiņas kultūru un ne tikai pārṇem, bet pārkārto kolektīvo atminu un definē savu vietu vēsturiskajā procesā. Kā identificēt paaudzi, cik tā ir viendabīga, un kādas ir paaudzes robežas? Nodarbojoties ar mutvārdu vēsturi, strādājot ar biogrāfiskajām intervijām, mums daudzie dažāda vecuma cilvēku dzīvesstāsti kalpo par paaudzes liecību. Cilvēkiem reflektējot par savu dzīves gājumu un tā vai citādi lokalizējot sevi vēstures procesu kontekstā, atmiņu stāsti sniedz iespēju identificēt paaudzi. Raksta noslēgumā, balstoties uz atbilstošiem atradumiem pasaules pētījumos un analizējot Nacionālās mutvārdu vēstures dzīvesstāstu kolekciju, gribam piedāvāt savu skatījumu uz mūsu sabiedrības paaudžu struktūru.

\section{Paaudžu jautājums sociālajās zinātnēs}

Paaudžu jēdziena lietojums sociālajās zinātnēs un publiskajos diskursos bieži ir ḷoti patvalịgs un nenoteikts un var apzīmēt atšksirīgus lielumus. Par paaudzēm var runāt kontekstā ar

Bristow 2016. gímeni vai vēsturi, attiecībā uz dzimšanas laiku vai vecumu, saistībā ar pēctecību vai vienlaicību. Visbiežāk jēdzienu lieto, ar to saprotot “ǵimeniskās paaudzes", kas apzīmē zināmu radniecības iedalīšanas principu, un paaudzes būtībā ir distance starp vecākiem un bērniem. Te pētnieki diskutē, kāds ir "tēvu-dēlu" nomaiñas ritms - vai paaudzes garums ir 10-15 vai 30 gadi, jo jāṇem vērā dažādu kultūru un laikmetu atškirīgie priekšstati par to, cik ilgi ilgst bērnība un kad iestājas briedums vai vecums. Šis t. s. ǵenealoǵiskais skatījums veido paaudžu konceptualizācijas vertikālo asi, kur definējums ir saistīts ar dzimtu un pēctecību, uzsvaru liekot uz sabiedriskās dzīves kontinuitāti un reprodukciju². Otrs skatījums, ko vēlamies uzsvērt, ir saistīts ar demogrāfiju un sociokulturālām izmaiņām, kuru aprakstīšanai arī lieto paaudžu jēdzienu, bet jau citā nozīmē.

Šajā rakstā analizētās paaudzes nav tikai nepārtraukti un cikliski viena otru nomainošu vecumgrupu un radniecības "vecāki-bērni" ķēde. Visupirms tā ir vienā laikā dzimušu cilvēku kopa, un tas paver horizontālo perspektīvu uz paaudzēm kā kohortā bāzētām sociālām lokācijām. Ar kohortām saprot kādu līdzīga vecuma cilvēku daudzumu, kas vienlaicīgi saskaras ar noteiktu demogrāfisku notikumu (dzimšanu, iestāšanos skolā vai absolvēšanu, ǵimenes dzīves sākšanu u. tml.). Tomēr kohortai, atškirīīā no paaudzes, ir šaurāka un formāla nozīme, kuru turklāt piedēvē no ārpuses - šīs vecumgrupas nošķir institūcijas (skola, armija) un konstruē pētnieki statistisku aprēḳinu nolūkā, piedevām cilvēki ar tām neidentificējas. Lai gan paaudzes atskaites punkts ir kādā noteiktā periodā dzimis cilvēku daudzums, tomēr par noteicošo faktoru kḷust laikabiedru savstarpējā piederības sajūta, kas balstās uz kādu kopīgi veidojušos pieredzi, nevis biologiskais vecums. Kopējā pieredze, ar to saistītās vērtības un tādējādi attieksmes un uzvedības iezīmes kḷūst par paaudzes apraksta stūrakmeni. Viens no pirmajiem, kas paaudzes izpratnē apvienoja objektīvos dzimšanas laika, vecuma bioloǵiskos faktorus ar kultūras un subjektīvo interpretāciju lomu, bija sociologs Karls Manheims (1893-1947). Piederība pie vienas paaudzes vai vecumgrupas,

\footnotetext{
2 Burnett 2010.
} 
viņš rakstīja savā programatiskajā darbā, "pieškiir šiem cilvēkiem kopīgu vietu sociālā un vēsturiskā procesā un tādējādi nosaka robežas konkrētai potenciālai pieredzei, predisponējot tos noteiktam domāšanas un pieredzes veidam un raksturīgai vēsturiskai darbībai"3.

Klasiskajā izpratnē paaudze formējas kā īpašs sociālais stāvoklis, ko nosaka tas, ka cilvēki piedzīvo sev nozīmīgu vēsturisku pieredzi, un, to kopīgi pārdzīvojot, veidojas zināmā mērā līdzīgas reakcijas, kas izpaužas turpmākajā dzīvē. Paaudzes aizmetņi veidojas socializācijas procesā. Pieaugot mēs pārejam no vienas vecumgrupas citā, bet piederība pie paaudzes tiek saglabāta visu mūžu. Konkrētos laikmeta notikumos transformējas vērtību sistēmas, kuras iemieso, nes tālāk un realizē tās cilvēku grupas, kas tai brīdī atradās plastiskā vecumā, t. i., jaunībā. Manheims uzskatīja, ka svarīgi ir tie notikumi, kas risinās kādas personas jaunībā, un būtisks ir tieši "svaigais kontakts" ar pasauli, kura laikā tad veidojas gan konkrētu cilvēku, gan paaudzes identitāte. Vēsturiskā konteksta nozīmību jaunības gados ir apstiprinājis ASV pētnieku darbs. Viņi veikuši plašu empīisku izpēti, analizējot vēsturisku notikumu svarīgumu dažādu vecumgrupu kolektīvajā atmiņā, secinot, ka atmiņā izteiktākie ir tieši notikumi jaunībā, un katrai paaudzei tie ir atšksirīgi ${ }^{4}$.

Kopš Manheima kanoniskā teksta publicēšanas ir nostiprinājusies pieeja paaudzes tvert kā kultūras fenomenus sociālās struktūras ietvaros, nereducējot tos uz biologisko pēctecību. Pētnieki analizē noteiktu kohortu pozicionēšanos vēstures norisē, kur jāvērš uzmanība uz mijiedarbību starp jauniem dalībniekiem kultūras procesā. Jans Asmans atzīmēja, ka paaudžu atmiņa tiek iegūta vēsturiskā ceḷā un ir cieši saistīta ar šīs atmiņas nesējiem, kuriem mirstot vieta tiek dota jaunām atmiṇām. Šāda atmiņa, pēc viṇa domām, var pastāvēt 3-4 paaudzes. ${ }^{5}$

Straujais vēsturisko notikumu ritms un sociālo izmainu temps ir stimulējis rakstnie$\mathrm{ku}$, publicistu un pētnieku interesi par paaudžu identificēšanu, nosaukšanu un to aptuveno

\footnotetext{
3 Mannheim 1997, 291.

4 Corning, Schuman 2015.

5 Assmann 2013, 50.
}

robežu iezīmēšanu. Nozīmīgu iespaidu uz paaudžu atšķirīibu teorijas attīstību un popularizāciju atstāja Viljama Strausa un Neila Hova sarakstītās grāmatas par paaudzēm ASV vēsturē $\bar{e}^{6}$. Par paaudzi viņi uzskata cilvēku grupu, kurus ietekmējuši tie paši notikumi un sociālekonomiskie apstākḷi konkrētajā, vienojošajā laika sprīdī. Saskaņā ar viņu paaudžu atšksirību koncepciju, cilvēkiem, kuri dzimuši aptuveni ik pēc 20 gadiem, ir kopīgas iezīmes, kas izriet no vēsturiskās pieredzes, sabiedriskiem nosacījumiem, kā arī tehnoloǵiskajām u. c. norisēm. Turklāt viņi uzsver, ka paaudžu nomaiņai ir raksturīgs cikliskums. Autori izmanto pētnieciskajā un populārajā literatūrā atrodamos paaudžu apzīmējumus: "dižā paaudze", "klusā paaudze", "Baby boom" un "X paaudze", "tūkstošgades paaudze", "Z paaudze". Lai arī šāda pieeja izskatījās visnotal origínāla un pievilcīga, taču tā tiek kritizēta par to, ka tā rada dažādus grupu stereotipus, kurus izmanto mārketinga speciālisti, politiķi un masu mediji.

Ir pētnieki, kas paaudzes nozīmību pēdējā laika sabiedriskajā attīstībā liek pāri tradicionālajam škiriskajam dalījumam ${ }^{7}$. Sociālās stratifikācijas kontekstā paaudze tiek nodalīta no hronoloǵiski definētas (mūža gadu) kohortas, lai arī, to iekḷaujot definējumā, paaudze tiek saprasta kā vecumgrupa, kas kḷūst sociāli nozīmīga, konstituējot sevi kā kultūras identitāti. Analizējot Latvijas situāciju, ir svarīgi saprast, ka paaudzes veidošanos nosaka arī dramatiski vēsturiski satricinājumi, jo tā ir "kolektīvā atbilde traumatiskam notikumam vai katastrofai, kas tad apvieno noteiktu indivīdu kohortu ar pašapziņu apveltītā vecumgrupas slān̄̄”. Te gan jāṇem vērā, ka ne vienmēr vecumgrupas kohorta apliecina kādu identitāti un tiek apveltīta ar tādu pašapziņu, lai rastos pamats to uzskatīt par paaudzi stingrā nozīmē. Par paaudzi kā iespējamību, kā potencialitāti vai aktualitāti rakstīja jau Manheims. Elisters Tomsons, pamatojoties uz mutvārdu vēstures intervijām ar vairākiem simtiem austrāliešu, savā pētījumā apgalvo, ka cilvēkiem savā vecuma kohortā var būt vēsturiski atskaites

\footnotetext{
6 Strauss, Howe 1991 u. c.

7 Edmunds, Turner 2002.

8 Turpat, 12.
} 
punkti, tomēr šīs kohortas ne vienmēr apzinās sevi kā atšksirīgu paaudzi ${ }^{9}$. Viņš piekrīt, ka paaudzes tiek kaldinātas jaunības gadu kopīgā iespaidīgā pieredzē. Pēc tam paaudžu pašapziņa tiek veidota un konsolidēta to cilvēku atmiņā, kas izmanto paaudzes kolektīvās identitātes reprezentācijas savas biogrāfijas izpratnē. Analizējot intervijas, viņš nonāk pie slēdziena, ka pašā pēckara Austrālijas sabiedrībā ir tikai viena t. s. "60. gadu paaudze". Arī mūsu regionā šĩ ir pieminēšanas vērta paaudze ${ }^{10}$, taču vai ar tādu pašu nozīmi Latvijā?

\section{Ieskats paaudžu pētījumos Latvijā un valstīs ar līdzīgu vēsturisko pieredzi}

Lai kartografētu Latvijas sabiedrības paaudzes, ir vērts ielūkoties kaimiņu zemju pētnieku darbos, kur līdzīgu vēsturisku procesu rezultātā varētu būt veidojušās salīdzināmas paaudžu kopas. Postkomunistiskajā Austrumeiropā atšķirīgās paaudzes aprakstījuši Krievijas sociologi, pētnieki Polijā, bijušajā Dienvidslāvijā un Igaunijas antropologi, kas izmanto mutvārdu vēstures pieeju. Savā grāmatā, jautājot, "kā paaudzes atceras", Monika Palmbergera ${ }^{11}$ ir analizējusi dažāda vecuma cilvēku naratīvus par pagātni Dienvidslāvijā. Viṇa identificē trīs dažādas paaudzes atkarībā no tā, kā tās pozicionē sevi attiecībā pret vietējās vēstures dominējošiem naratīviem, īpaši saistībā ar vairāku karu pieredzi šajā reǵionā. Līdzīgu paaudžu dalījumu piedāvā cita pētniece, analizējot ukraiņu minoritāti, kas pārvietošanas rezultātā nonākusi Polijas ziemeļos ${ }^{12}$. Pētījumā par kolektīvo atminu un nacionālo identitāti Aleksandra Vanglere par savu uzdevumu uzskata paaudžu atškirīību aprakstīšanu attiecībā uz nacionālās identitātes veidošanos un vēsturisko notikumu interpretāciju. Analīzes gaitā paaudzes, saskaņā ar Manheimu, tiek definētas atkarībā no cilvēku pieredzētiem notikumiem "formējošā vecumā" jeb jaunībā (starp 12 un 24 gadiem), kas tad nosaka atcerei būtiskus pagātnes references punktus un

\footnotetext{
9 Thomson 2016, 276-320.

10 Vails, Genis 2006; Voronkov 2005; Valpēters 2010.

11 Palmberger 2016.

12 Wangler 2012.
}

caur to tagadējās situācijas interpretāciju, tai skaitā arī viṇu nacionālās identitātes izpratni.

Krievu sociologs Jurijs Levada, izstrādājot savu paaudžu struktūru, atzīmējis, ka paaudzes sociālā nozīme nevar tikt mērīta ar "vairākuma" vai "masu" noskaņojumiem un pieredzēm, ko reprezentē sociālo aptauju rezultāti ${ }^{13}$. Vēstures procesa socioloǵiskajā analīzē ir jārēkinās nevis ar demogrāfiskām grupām, bet ar noteiktām nozīmīgām paaudžu grupām vai struktūrām. Viena liela perioda, piem., gadsimta ietvaros, var tikt izceltas paaudzes, kas nosaka noteiktus uzvedības piemērus vai rāmjus, domas, noteiktu simbolu komplektu u. c. paaudzes raksturlielumus. Paaudzes tēli veidojās noteiktās grupās, kuras var būt masveidīgas vai arī elitāras. Ja sekojam elitārajai paaudzes koncepcijai, kura akcentē personību lomu visas paaudzes (un ne tikai), pagātnes, vērtību un nākotnes ilgu formēšanā, tad veidosies savdabīga 20. gadsimta paaudžu struktūra, no kuras daudzi "mazie" vēstures subjekti vienkārši izkrīt ārā. Latvijā kā piemēru varam minēt t. s. nacionālkomunistus, kuru darbība 50. gadu beigās ir akcentēta tikai elites - partijas, zinātnes, kultūras pārstāvju - dzīvesstāstos, turpretim lielākajam vairākumam šis politiski nozīmīgais process paliek nepamanìts, un par to cilvēki nereflektē. Tāpat jāṇem vērā, ka mutvārdu un dzīvesstāstu projektu galvenais motīvs ir bijis dot vārdu tiem slāṇiem, kas lielajos vēstures naratīvos tiek ignorēti.

Visa vēsture ir paaudžu nomainas process, bet tas, cik atškirīịi rit vēsturiskie notikumi dažādos pasaules reǵionos, nosaka paaudžu līdzības vai atškirīības konkrētajās sabiedrībās. Mums vistuvākās pagājušā gadsimta vēstures procesos ir Baltijas valstis, un tur pētnieki ir mēǵinājuši sistemātiski pievērsties paaudžu analīzei. Tāpēc viņu sniegums mums ir loti būtisks, velkot paralēles un izstrādājot savu vēsturisko paaudžu koncepciju. Vadošo jomas pētnieku ilgstošais darbs, "kartografējot paaudzes Igaunijas kontekstā", jau ir apkopots grāmatā, kas iznāca 2016. gadā ${ }^{14}$. Viṇi izmanto gan demogrāfisko pieeju un vērtību statistisko analīzi, gan arī kvalitatīvo pieeju, lai caur mutvārdu vēsturi un atmiṇu stāstu prizmu saskatītu

\footnotetext{
13 Levada 2011, 123-125.

14 Nugin et al. 2016.
} 
laikabiedru diferenciāciju atškiirīgās paaudzēs. Igauṇu pētnieki, kas balstās uz kvalitatīvajām metodēm, vērš uzmanību uz to, kā cilvēki, kas piedzīvojuši tos vai citus laikmeta notikumus, atceras savu bērnību pirmskara laikā, kā izsaka un vērtē savu padomju laika pieredzi, kā konstruē stāstus un kādus vadmotīvus vai šablonus lieto. Šìs atminu diskursīvās prakses tiek interpretētas kā noteiktām paaudzēm raksturīgas. Konsekventāk Igaunijas sabiedrības paaudzes konceptualizējusi socioloǵe un dzīvesstāstu pētniece Aili Ārelaida-Tarta (1947-2014) ${ }^{15}$. Viņa piedāvā šādu paaudžu dalījumu:

1) “Republikas paaudze", kas dzimusi 20. gs. 20. gados, bet savā pieaugšanā, saskaroties ar mainīgiem politiskiem režīmiem, ir saskaldīta vairākos segmentos;

2) 1930.-1945. gadā dzimušo paaudzes kohorta, kas kā bērni vai pusaudži piedzīvojusi karu, deportācijas un teroru ("beztēvu paaudze");

3) pirmā īstā "pēckara paaudze", kas uzaugusi padomju mentalitātes apstākḷıos un dzimusi galvenokārt 50. gados, tāpēc pašai nav personisko atmiņu par neatkarības laiku, bet nācās realizēties sociālisma apstāklıs;

4) "80. gadu pusaudži”, kuri dzimuši ap 1970. gadu un kuru personības veidojās sociālisma destabilizācijas un sabrukuma apstāklılos, bet padomju laiks tiek aplūkots ar bērnības acīm;

5) "atjaunotās neatkarības bērni”, kas dzimuši jau pēc 1991. gada un ieklaujas globalizētās pasaules norisēs.

To, cik līdzīgi paaudžu formēšanos analizē Lietuvā, var redzēt dzīvesstāstu pētnieces Laimas Žilinskienes un britu vēsturnieces Melānijas Eilikas darbā ${ }^{16}$. Pētījumā par ǵimenisko vērtību izmaiṇām Lietuvā 20. gadsimtā par pamatu ņemta biogrāfiskā metode, kas l̦auj koncentrēties uz sociālo subjektu noteiktā sociālā struktūrā ilgstošā vēsturiskā periodā. Par svarīgiem markikieriem paaudžu noškiriršanā viņas ir uzskatījušas paaudzes socializāciju, uzvedības modeluus, attiecības ar citām paaudzēm, kā arī dzīvesveidu un identitāti. Pētnieču skatījumā, balstoties uz intervijām un dzīves gājumiem,

\footnotetext{
15 Aarelaid-Tart 2011.

16 Žilinskienè, Ailic 2018.
}

var izdalīt sešas paaudzes. Atskaites punkts ir 1925.-1930. gadā dzimusī Lietuvas Republikas paaudze; tai seko 1931.-1944. gadā dzimusī "stalinisma laika" paaudze; pēc kuras nāk 1945.-1959. gadā dzimusī "pirmā padomju" paaudze un 1960.-1969. gadā dzimusī "atkušņa" paaudze; kā piektā tiek nodalīta "pēdējā padomju paaudze" (1970.-1979. gadā dzimušie) un, visbeidzot, 1980.-1990. gadā dzimušie kā "pirmsneatkarības laika" paaudze.

Minētās koncepcijas par pagājušā gadsimta paaudžu struktūru lielā mērā sakrīt ar politiskās vēstures periodizāciju, un atsevišķos gadījumos šì vēsture bija līdzīga vai pat kādu laiku kopīga ar Latviju. Tomēr var redzēt, ka tas nevar tikt automātiski attiecināts uz mūsu valsts iedzìvotāju paaudzēm, kuras formēja citādāka vēstures pieredze gan saistībā ar Latvijas Republikas pastāvēšanu 1918.-1940. gadā un tās okupāciju Otrā pasaules kara gados, gan arī saistībā ar atšķirīgiem kolonizācijas un demogrāfiskiem procesiem pēckara gados.

Latvijā pētījumi, kur pieminētas paaudzes, ir veikti dažādās jomās, pašu paaudzes jēdzienu gan dažkārt teorētiski nenodalot no vecumgrupas vai kohortas, kad cilvēku kopums tiek iezīmēts atkarībā no dzimšanas gada jeb dzīves cikla izmaināām. Latvijas Universitātes pētnieces Ilzes Koroḷevas vadībā ir labi attīstīta jaunatnes izpēte (uzskati, līdzdalība, atkarības), kā arī ir veikti pētījumi par sabiedrības novecošanu (senioru statuss, aprūpe, "eidžisms"). Īpaši paaudzes salīdzinātas profesiju prestiža un izvēles mērījumos, analizējot datus par jauniešiem padomju laikā un mūsdienās ${ }^{17}$. Paaudzēm kā vecumgrupām savus pētījumus ir veltījis LU Demogrāfijas centrs (beidza pastāvēt 2013. gadā), kas reǵistrēja iedzīvotāju sastāva un struktūras izmaiņas un analizēja tendences šajā jomā. Mutvārdu vēstures pētniece Irēna Saliniece pētījumā par ǵimenes paaudzēm Latvijā un kolektīvo atmiṇu izceḷ četras paaudžu grupas, atzīmējot to atšķirīgo vēsturisko pieredzi, tomēr sīkāk š̄ problēma rakstā nav analizēta. ${ }^{18}$

Jāatzīst, ka mērḳtiecīga un dziḷāka paaudžu raksturojuma konceptualizācija Latvijā nav notikusi. Ar to pēdējā laikā ir sākuši

\footnotetext{
17 Koroleva et al. 2014.

18 Saliniece 2015, 24-25.
} 
nodarboties personāla vadības un mārketinga speciālisti. Parasti tiek izmantots Eiropā vai ASV izveidotais dalījums (sākot ar "varonīgo paaudzi" un beidzot ar "milēniuma" un "Z paaudzi”). Kā galvenā metode pētījumos tiek izmantota aptauja ar iepriekš izstrādātiem apgalvojumiem, lai raksturotu respondentu attieksmes. Tiek mērīti tādi parametri kā konservatīvisms, atvērtība jaunajam, gatavība uznemties risku, darba ētika, lojalitāte un tamlīdzīgi. Paaudžu problēma tiek aktualizēta valdības pasūtîtos pētījumos par jaunatnes piesaisti un integrēšanu valsts pārvaldē, piem., vēršot uzmanību uz to, kas "Y paaudzes" (dzimuši pēc 1980. gada) darbiniekus un darba meklētājus padara atšķirīgus no iepriekšejo paaudžu nodarbinātajiem. Patērētāju segmentu analīzē ir parādījušies Latvijas situācijai adaptēti paaudžu "anatomijas model̦i" (izdzīvotāji, pārmaiṇu bērni u. c.), plašsazinas līdzekḷos apspriež mūsdienu "digitālās paaudzes"19.

İpaši ir jāatzīmē paaudžu pieminēšana LU SZF Sociālo un politisko pētījumu institūta zinātnieku pētījumos projektā "Latvijas sociālā atmiņa un identitāte" (vadītāja prof. Vita Zelče). Lai gan pētnieki izmanto paaudžu jēdzienu, šì sociālā kategorija tiek pieņemta kā dotums un to lieto normatīvisma nozīmē (t. i., vecākiem vai citiem aǵentiem pieredze jānodod laikabiedriem un jāsaglabā pēctečiem). Kā paaudzes veidojas, pašidentificējas un kāda ir ne tikai vecumgrupu, bet arī noteiktu paaudžu atmiņu savstarpējā mijiedarbe, te netiek analizēts. Zināmu ieskatu paaudžu "vēsturiskās socializācijas" aspektos sniedz arī dažādas aptaujas, kur izdalītas noteikta vecuma respondentu kopas ar savu attieksmi pret pagātnes notikumiem $^{20}$.

Šajā rakstā vēlamies izvairīties no paaudžu identificēšanas tikai ar vecuma vai statusa grupām, tādēḷ uzskatām, ka ir uzmanīgi jānoskaidro personisko atmiṇu nozīme paaudzes pašapzin̄ā un jācenšas izsekot, kā veidojas noteikti naratīvi starp cilvēkiem ar atškirīgu pieredzi. Dzīves stāsta intervija ir viens no veidiem, kas l̦auj visciešāk pietuvoties nozīmju un jēgu pasaulei, ko cilvēks pasniedz

19 Gudule, Pētersons 2012.

${ }^{20}$ Sk., piem., Kaprāns, Procevska 2013; Kaprāns, Saulītis 2017. caur saviem naratīviem saskaņā ar gūto pieredzi. Nacionālais mutvārdu vēstures projekts šim pētījumam ir būtisks izpētes resurss, jo tas veidots, lielu uzmanības dalu veltot tieši vecāka gadagājuma cilvēku atmiņām. Viņi piedzīvojuši divus pasaules karus, brīvvalsts laiku un okupācijas varu maiņu, tādēl var sniegt ne tikai unikālas liecības, bet arī bāzes informāciju paaudžu pieredzes, atminu un stāstīšanas stratēgiju salīdzinājumam un atklāt to ietekmi uz Latvijas sabiedrību un kultūru 20.-21. gadsimtā.

\section{Paaudžu marḳieri}

Kolektīiās atmiņas paaudzes ir vieglāk nodalīt, ja raugāmies uz noteiktu paaudžu kohortu attiecībām ar nozīmīgiem un lieliem vēstures notikumiem, tomēr šāda pieeja apgrūtina veidot visaptverošu skatījumu uz 20. gadsimta vēstures enkuriem iedzīvotāju naratîvos. Piedevām šāda pieeja l̦auj koncentrēt uzmanību uz cilvēka attiecīibām ar konkrētu vēstures procesu un atmiņu par to. Ja izmantojam šādu pieeju, iespējams minēt tikai nedaudzus vēstures procesus, kas būtu naratīvās analīzes vērti. Pirmkārt, tas būtu Latvijas Republikas (1918-1940) vērtējums un attieksme pret notikumiem (arī pret Kārḷa Ulmaņa diktatūru) šajā laika posmā. Otrkārt, akcentēšanas vērti būtu dramatiskie Otrā pasaules kara notikumi un to seku paliekas (okupācija, sovetizācija, holokausts, karš, atkārtotā padomju okupācija, došanās bēgḷu gaitās, nacionālo partizānu karš, deportācijas, staḷinisms) individuālajos dzīvesstāstos (1940-1953). Treškārt, analīzes vērts būtu tas, kā un cik lielā mērā cilvēki reflektē par posttotalitāro padomju periodu, sākot ar Josifa Stalina nāvi 1953. gadā un beidzot ar Mihaila Gorbačova aizsāktās pārbūves un atklātības procesu tiešu ietekmi uz pagātnes pārvērtēšanu, kas Latvijā aizsākās ap 1987. gadu.

Šāda analīze sniegtu detalizētāku un izsvērtāku noteikta perioda attēlojumu individuālajos dzīvesstāstos, tomēr tā nespētu sniegt visa pagājušā gadsimta kopainu Latvijas iedzīvotāju dzīvesstāstos. Visaptverošu ainu traucē veidot arī Latvijas iedzīvotāju saskaldītā atmiņa. Tā, piem., pēc Otrā pasaules kara no PSRS ieradušos iedzīvotāju atmiņas ir citādākas nekā 
to Latvijas iedzīvotāju atmiņas, kuri te dzīvojuši izsenis, īpaši tas attiecas uz 20. gadsimta otrās puses vēstures notikumu traktējumu un pieredzēm, kas nav saistītas ar Latviju pirms 1940. gada. Tādējādi, veidojot paaudžu pagātnes atmiņu struktūru un vērtības, kas tajās atklājas, nāktos ņemt vērā arī atmiņu etnisko un vēsturisko raksturu.

Turklāt plūstoša pāreja no vienas paaudzes uz citu var notikt tikai tradicionālā sabiedrībā, kur tā notiek gimenes ietvaros. Sociālpolitiskā vēsture, īpaši šodienas - posttradicionālā -, ir piesātināta ar pagriezieniem, saviḷnojumiem, masu ilgām, vilšanos un kompleksiem, kas rada "nozīmīgas paaudzes", kuras nosaka toni (orientācijā, simbolos, vērtībās) samērā ilgu laiku, ar paaudžu plaisām pieredzēs un vērtējumos, ar konfliktiem starp "tēvu" un "dēlu" paaudzēm utt. ${ }^{21}$ Šìs paaudzes parasti pašidentificējas vai tiek izdalītas, lai noteiktu kāda noteikta procesa ietekmi uz attiecīgā vecuma kohortu. Pasaulē ir daudz marķieru, kas palīdz atrast šīs paaudzes un izvērtēt to ietekmi uz turpmākajiem vēstures procesiem. Jau Manheims kā piemēru apskatīja 19. gadsimta franču un vācu revolucionārās paaudzes un ar tām saistītās jauniešu kustības. Arī vēlāk pētnieku darbos radikālas transformācijas, karš un diktatūras vai terora pieredze ir bijusi par pamatu, lai identificētu reǵionāli specifiskās paaudzes. Īpaši šeit var izcelt Spānijas traumatisko pieredzi un ar to saistīto paaudžu atmiņu (un to noklusēšanu) vai Vācijas pētnieku mēginājumus izprast paaudzes pēc to atmiņas par nacionālsociālistisko diktatūru ${ }^{22}$.

Modernās teorijas par paaudžu veidošanos un diferenciāciju savulaik veicināja pievēršanos vienai - "1914. gada" - paaudzei, kuru radīja t. s. Lielais karš, kas tiešām bija ekstremāls satricinājums. Eiropas kultūras atmin̄ā ir nostiprinājies amerikāņu rakstnieces Ģertrūdes Stainas izteikums par saviem laikabiedriem, ka viņi esot "zudusī paaudze". Tādi rakstnieki kā Ernests Hemingvejs un Ērihs Marija Remarks ir aprakstījuši šīs paaudzes postošo pieredzi. Eriks Hobsbaums savā vēstures izpētē par “īso 20. gadsimtu” ir pamatojis, ka pagājušais

${ }^{21}$ Levada 2011, 123-124.

${ }^{22}$ Frei 2009, 38-55; Caballero, Baigorri 2018, 14-17. gadsimts ir sācies faktiski tikai līdz ar Pirmo pasaules karu ${ }^{23}$.

Raksturojot Padomju Savienības paaudžu problemātiku, parādās "sešdesmito gadu paaudze", kuras veidošanās stūrakmens bija 1956. gads ar tajā notikušo PSKP XX kongresu, kurā N,ikita Hruščovs vērsās pret Staliina kultu un tā pārspīlējumiem, kā arī šajā pašā gadā notikusī Ungārijas sacelšanās un t. s. Poḷu oktobris, kuru apspiešana liecināja par padomju sistēmas joprojām nedemokrātisko un agresīvo raksturu. Par šīs paaudzes pārstāvjiem kḷuva to vecuma kohortu pārstāvji, kas ieraudzīja iespējas izvēlēties perspektīvas, simulējot aktīvu intelektuālo darbu, meklējot savu ceḷu. Visbiežāk sociālā vide viniem nel̦āva pārvarēt ideoloǵiskās dogmas un ierastos uzvedības stereotipus. Tomēr šai paaudzei pieauga iespējas iegūt informāciju no ārzemēm, tā sāk mācīties svešvalodas, bet jaunatnes aprindās raksturīgā tieksme pēc ārzemju mūzikas noved pie pieredzes klausīties ārzemju radio ikdiena $\bar{a}^{24}$.

Līdzịgs populārs marķieris Rietumu pasaulē ir t. s. "68. gada paaudze", ko cieši saista ar tajā laikā notikušo jaunatnes dumpi un šīs paaudzes ideāliem, kas vēlāk tiek realizēti politiskajā dzīvē. Tomēr arī šāds marķieris izraisa iebildumus, minot, ka Vācijā vien var runāt par trīs dažādām 1968. gada paaudzēm Rietumvācijas paaudzi, tās antipodu - labēji noskaņoto kontrpaaudzi un Austrumvācijas paaudzi, kuras mērķi un metodes atšķīīās no Rietumvācijas “dumpja” un kuras protesti tika nesaudzīgi apspiesti ${ }^{25}$.

Saprotams, eksistē arī citi markieri, ko nosprauduši paši paaudzes pārstāvji vai arī masu mediji. Te varam minēt "kara bērnus", kas dzimuši 30. gadu beigās un 40. gadu sākumā. Viņi pašlaik sasnieguši pensijas vecumu un atgādina par savas agrās bērnības pārdzīvojumiem - bombardēšanu, izdzī̌̌anu, tēvu zaudēšanu utt. Dažas no šìm atmiņām ir traumatiskas, un tām var būt nopietnas sekas viņu pašvērtējumā, dzīves mērķu un jēgas nospraušanā un psihiskajā stabilitātē. Tā kā ne tikai pusaudžu vecuma pieredzes spējīgas radīt

\footnotetext{
${ }^{23}$ Hobsbawm 1995.

24 Voronkov 2005, 176-177, 183-184.

${ }^{25}$ Goltz 2011, 473-490.
} 
ilgtermiņa paaudzes identitāti, bet arī citos dz̄̄ves posmos radušies pārdzīvojumi var veidot ipašas paaudzes identitāti. ${ }^{26}$

Latvijā līdz šim nav noteikti determinēti un publiskajā sfērā apspriesti vēsturisko paaudžu marķieri. Protams, ir bijuši mēǵinājumi, tomēr tie nedz zinātniskajā, ne mediju vidē nav nostiprinājušies. Tā nesen tapusī Laimas Žurginas filma Kaza kāpa debesīs (2019) ir aktualizējusi jautājumu par viņas paaudzes ietekmi uz kultūras un sabiedriskajiem procesiem Latvijā, ko jau pirms pāris gadiem skāra arī Eižens Valpēteris ar savu grāmatu Nenocenzētie $^{27}$. Savā veidā t. s. "Kazas paaudze" ir ekvivalents PSRS esošajai "sešdesmito gadu paaudzei”, tomēr, kā norāda kinokritiķe Kristīne Matīsa, ja "filmas mērķis būtu "paaudzes portrets", kā tas šur tur izskanējis, būtu jārunā par visu spektru - arī par tiem, kas nodzērās, pazuda laika miglājā vai vienkārši nodzīvoja ikdienišḳu proletārieša mūžu. Laima Žurgina tomēr izvēlējusies dot vārdu tikai veiksminiekiem un talantīgajiem - tiem, kas tagad Latvijas kultūrā ir pazīstami ar saviem darbiem un personības spēku"28.

Otra paaudze, ko mēgeina markiēt, bet ne visai veiksmīgi, ir t. s. "atmodas paaudze", kuru grūti ir noteikt, jo atmodas procesos bija iesaistītas dažādas vecuma kohortas. Piem., Juris Lorencs savā rakstā ar atmodas paaudzi saista tikai tālaika trīsdesmitgadniekus, atzīmējot, ka tie ir savā ziṇā īpaši ar to, ka ir stāvējuši vēstures krustcelēs: "Tātad cilvēki ar unikālu pieredzi. Mēs būsim pēdējā Latvijas paaudze, kas savā apzinīgajā vecumā piedzīvoja totalitāru valsts iekārtu un sociālistisko plānveida ekonomiku. Mēs būsim pēdējie, kuri katru gadu no jauna var skatīties Briljanta roku un smieties par jokiem, kurus jaunāki par mums vairs īsti nesaprot. Mēs būsim pēdējā paaudze, kas vēl sapratīs zemtekstus, līdz galam neizteiktus vārdus." ${ }^{29}$ Visumā emocionāls un pat trāpīgs apraksts, tomēr šim apzīmējumam var sevi pieskaitīt arī tālaika divdesmitgadnieki un četrdesmitgadnieki utt. Dzīvesstāstos ar neatkarības atjaunošanas procesiem sevi saista arī

\footnotetext{
${ }^{26}$ Reulecke 2008, 122.

27 Valpēters 2010.

28 Matīsa 2019.

29 Lorencs 2019.
}

daudz jaunākas paaudzes, īpaši, ja šajos procesos bija iesaistīti vinu vecāki vai vecākie brāḷi un māsas. Žēl, ka publiskās diskusijas par šiem jautājumiem Latvijā netiek attīstîtas plašāk.

Jāpiekrīt Klaudīnei Atias-Donfū un Sārai Arberai $^{30}$, ka "vēsturiskās paaudzes" sabiedrība atzīst aposteriori, identificē tās retrospektīvi. Tikai ar selektīvu pagātnes rekonstrukciju paaudze saistās ar noteiktu sociālu notikumu. Tas ir atminas un pieminas process. Pateicoties tam, sociālo notikumu uztur dzīvā paaudze, kas bijusi šì notikuma aculieciniece. Šis process uzliek paaudzei pienākumu kalpot kā vēstures kolektīviem lieciniekiem un kolektīvās atmiṇas nesējiem. Citiem vārdiem, tas, ko apzīmē ar "vēsturisko paaudzi" ir sociālo tēlu produkts, ko veicina sociālā laika uzbūve. Piederības sajūta konkrētai paaudzei rodas ne tikai caur horizontālo procesu, bet arī vertikāli - caur ǵimenes radurakstiem.

\section{Diskusijai: Latvijas paaudžu vēsturiskā identifikācija}

Pagātne neslēpjas atmināā, vinām ir jābūt skaidri formulētām, lai kḷūtu par atmiṇu. Valoda, kuru autors izmanto, lai to sasniegtu, vienmēr satur iepriekšējās pieredzes hierarhijas un tādā veidā ir cieši saistīta ar dominējošajiem vēstures diskursiem ${ }^{31}$. Tas labi parādās dzīvesstāstos, kur vērojama ietekme gan no iepriekšējo paaudžu pieredzēm, gan arī pagātnes metanaratīvu ietekme. Tas naratīva hronoloǵiskos ietvarus padara izplūdušus, bet reizē arī katrai paaudzei sniedz tikai tai raksturīgās iezīmes. Kā atzīmēja Mērija Falbrūka, paaudzes nav vienkārši dotumi, kolektīvi objekti, kas soḷo caur vēsturi nekad nemainīgas; drīzāk tās ir līdzīgas mainīgiem zvaigznājiem, kuru kontūras sajaucas un mainās atkarībā no tā, kad rodas jaunas problēmas un kad dažādi jautājumi par pagātni, tagadni un nākotni kḷūst aktuāli sabiedrībā $\bar{a}^{32}$.

Pamēgeināsim izvirzịt tās Latvijas 20. gadsimta vēsturiskās paaudzes, kuras iespējams konstatēt, ņemot vērā gan vēstures līkločus,

\footnotetext{
${ }^{30}$ Attias-Donfutand, Arber 2001, 3.

31 Sayner 2007, 3.

32 Fulbrook 2011.
} 
gan to atspoguḷojumu cilvēku dzīvesstāstos. Aizvadītajā gadsimtā mēs saskatām vismaz sešas skaidri definējamas paaudzes, kuras ilustrēsim ar dažiem piemēriem no intervēto cilvēku atmin̄ām.

1. Paaudze, kas dzimusi 19. gadsimta beigās un 20. gadsimta sākumā. To nosacīti varētu dēvēt par pirmo "neatkarīgās Latvijas paaudzi”, kas pieredzēja gan Pirmo pasaules karu, gan došanos bēgḷu gaitās uz Iekškrieviju, gan arī Latvijas valsts tapšanu un nostiprināšanos Neatkarības kara liesmās. Šai paaudzei ir dzīvas arī no vecākiem mantotās atmiņas par 1905. gada revolūciju, par "cara laiku” un norisēm tajā - izglītības iegūšanu, zemnieku sociālo stāvokli, māju iepirkšanu utt. Atškirīīā no nākamās paaudzes, netiek idealizēti Latvijas valsts pirmie gadi, bet tie pēc pašu pieredzes tiek aprakstîti kā "grūti laiki". Piem., 1892. gadā Zemgalē dzimušais Jānis ${ }^{33}$ stāsta gan par 100 ha saimniecību, ko tēvs nopircis no grāfa fon Pālena, gan par to, kāda bija tēva saimniecība. Turīgā zemnieku ǵimene atlaujas slimīgo zēnu sūtît uz Šveici ārstēties no dilona, lai tas nenomirtu kā vecākais brālis. Jāṇa sapņus par studijām Vācijā izjauc Pirmais pasaules karš:

Pirmā pasaules kara laik $\bar{a}$ mūs izdzina no mājām. Tad es Krievijā biju muižkungs vienā muižā. Es ar kaut ko piesavinājos. Tad, kad pārgājām mājās, sākām paši. Divi gadi pie têva par puisi nostrādāju, un tad es iestājos pilsētā tikai tāpēc, ka man tā sieva jau taisījās un tur es varēju piepelnit. Tad es to naudu vedu uz mājām... bet toreiz bija Latvijā-Zemgalē tāds stāvoklis: ja jums bija nauda, jūs nevarējāt nekā nopirkt, jums nekā nebija. Lauki neapsēti, ar zālēm aizauguši, mājas tukšas, visi lopiñi beigti, it nekā nebija.

Muižas sadalīja jaunsaimniecībās, mūsu pagastā kādas 80 radās. Bija tā Zemes banka jau nodibināta, papriekš vin̄iem piešk̦īa zemi, tad deva mežu materiālu par velti jeb par mazu summu, lai varētu būvèt èkas. Tās mājas sāka celt un iek̦īlāja Zemes bankā, un

${ }^{33}$ NMV-45, šeit un turpmāk kods intervijai, kas glabājas LU FSI Nacionālās mutvārdu vēstures krātuvē. dabūja aizdevumu. Par to aizdevumu sāka pamazām lopus iepirkt, zirgus. Tā kā mūsu laikā, kad Otrais pasaules karš uznāca, tad jau jaunsaimnieki bija uz pekām un diezgan labi dzīvoja.

Savukārt 1913. gadā dzimusī Elga ${ }^{34}$ stāsta par sava tēva iesaukšanu Krievijas impērijas armijā un dzīvi Rīgā līdz pat 1919. gada pavasarim.

Papus pārnāca no kara mājās. Karš bija beidzies, un visi laidās katrs uz savu pusi no cara armijas. Tad viņš sāka domāt par darbukādu laiku brauca tramvajā par konduktoru. Nodibinājās Latvijas valsts, tad nāca Sarkanā armija - viss vienā lielā mudžeklī. 1919. gada pavasarī boḷševiki vēl bija R̄̄gā. Dzīves te vairs nebija, un mēs braucām uz papus dzimto Vecsvirlaukas pagastu. Te tēvs sāk strādāt par mežsargu. Kad bija nostiprinājies darba vietā, tad papus meklēja dzīvesvietu, jo sava têva mājās nevarēja dzīvot - tās kara laikā bija nodedzinātas. Tad viňš sameklēja dzīvokli vienā saimniecībā. Tur mums bija viena liela istaba ar plīti visas mājas garumā. [..] Tad papus to mežsarga amatu atmeta un palika par skrīveri, un mēs pārvācāmies uz pagasta māju. [..] Sākumā viñ̌s strādāja viens, rīkoja vēlēšanas - pagasta valdes, padomes. Valsts bija pavisam jauna, vajadzejja visu rīkot.

2. Cilvēki, kas dzimuši 20. gados, veido t. s. "zudušās Latvijas paaudzi”. Tie ir cilvēki, kuru personības veidojās K. Ulmaņa autoritārisma gados un kuri lielā mērā saglabāja vēstures atminu par "labajiem Ulmaņa laikiem" un vēlāk kalpoja par pamatu daudzu Latvijas sociālpolitisko mītu veidošanai, kā arī Latvijas valsts neatkarības idejas vitalitātes nodrošināšanai. Šai paaudzei bieži ir raksturīgs konservatīivisms un eksaltēts patriotisms. Uz šīs paaudzes pieredzi milzīgu nospiedumu atstāja padomju okupācija, terors un Otrais pasaules karš, sabradājot viṇu jaunību, iesaucot vienas vai otras okupētājvalsts armijās, pakḷaujot arestiem, izsūtīšanām, sagraujot ierasto dzīvesveidu. 1921. gadā dzimusī Maiga ${ }^{35}$ stāsta:

\footnotetext{
34 NMV-3062.

35 NMV-90.
} 
Kad sākās karš, jau varēja dzirdèt, ka uz jūru kaut kur šauj, pāri nāca lidmašinnas, meta bumbas. Panika, nezina, kur mukt, ko darīt. Kādu nedēlu neko nedarījām. Kad krievi atkāpās, ienāca arī mūsu sètā, noguruši, mamma dalīja maizi, pienu. Viṇi brīnījās, kā mums var būt person̄̄gās govis. Šḳūnī gāja gulèt un tad aizgāja pavisam. Tad ienāca vācieši ar motocikliem. Mums jau mazpulkos nometnēs tika mācìts, ka vācieši ir galvenie ienaidnieki, par krieviem vispār nekas netika mācìts, tumša bilde, kas tur par iekārtu. Kad atkāpās, pienāca tā māja pilla ar vāciešiem.

Tālāk stāsts vēsta arī par vīra arestu un līdzšinējās dzīves kārtības sabrukumu pēckara gados.

3. 30.-40. gadu sākumā dzimušos var dēvēt par "karalaika bērnu paaudzi", un viņu atmiņa saistās ar dramatiskajiem kara notikumiem, vecāku zaudējumiem, pēckara sovetizāciju un 1949. gada deportācijām. 1927. gadā dzimusī Helena ${ }^{36}$ labi atceras sava tēva - Latvijas robežsarga - apcietināšanu 1940. gadā un ilgus gadus valdošo neziņu par viņa likteni. Tāpat viņas dzīvesstāstā dramatiski aprakstīta arī došanās bēg̣̣u gaitās 1944. gadā un nokḷūšana vācu nometnē.

Tad mēs pamazām devāmies Rīgas virzienā, lìdz Rìgai tikām, cauri Rìgai izgājām. Kad mēs bijām jau tikušas aiz Rīgas, krievi pārrāva fronti. Kājām mēs aizcel̦ojām lìdz Kandavas rajona Zemìtes pagastam. Tur mēs kādu mēnesi vai vairāk nodzīvojām. Naktī mūs aplenca vācieši, šucmañi, aizveda uz Kandavas staciju, ielika lopu vagonā un atveda uz Ventspili. Un pēc tam mūs aizveda ar kuği uz Vāciju, uz nometni. [..] Kad mēs gājām pa pussalu no Kēnigsbergas uz Dancigu, tur bija nepārtraukta apšaude, nepārtraukta bumbošana un nepārtraukti plūda bēgl, straume un mūs visus dzina. Mēs jau bijām apsargāti.

Pretim nāca vācu karspēks. Bija šausmīgi jāsargās no vāciešiem, kas bēga ar saviem trijjūgiem, lai mūs nesabrauc. Tā mēs maisījāmies kā tādā biezputrāa, kamēr aizgājām lìdz Dancigai. Apsargāja tikai mūs. Iznāca tā, ka mēs septiņas dienas nedabūjām neko èst. Kad ieraudzījām sasalušu lopu biešu stirpu,

${ }^{36}$ NMV-1654. mēs visi drāzāmies tur, nebaidīdamies no tā, ka nošaus vai kas tur notiks. Tie paši vācieši bija šausmās laikam, ieraudzìdami, kā mēs visi tur drāzāmies un grauzām tos kālus. Pēc tam, saprotams, visādas sekas bija. Mēs jau nedrīkstējām no cel̦a noiet malā, soli pāri grāvim, tad nošāva. Tã mums bija.

Turpinājumā tikpat dramatiski ir atainota arī mātes un meitas atgriešanās okupētajā Latvijā 1947. gadā un grūtības, ar kurām nākas saskarties, meklējot dzīvesvietu un darbu.

Cita šīs paaudzes pārstāve - 1936. gadā dzimusī Elma ${ }^{37}$ - atzīst:

Karš visu izjauca, katrs aizgāja uz savu pusi. Kara laikā mājās palika tēvs, māte un trīs pēdējie bèrni-es, māsa un brālis Paulis. Mums l̦āva dzīvot pēc tam arī krievu laikā. Māsa vēl tagad vasarā atbrauc pie mums padzīvot. Māsa aizgāja uz Fizkultūras institūtu mācìties, sāka strādāt par skolotāju Aizputē. Tur apprecējās ar fiziki, jaunu skolotāju, un aizgāja atpakal uz Vefu. Tā viņi palika par rīdziniekiem.

Vecākais brālis Arvīds bija mazpulkos, iemācījās amatus, visus lauku darbus. Viņu aizsūtīja uz Vāciju darba dienestā. Viňš arī vairs atpakal neatnāca, tur ieprecējās un palika. Edgars, vidējais brālis, aizgāja uz Rīgu uz Politehnikumu mācīties, turpat no skolas sola vinu pañēma leǵionā. Viņš atnāca kājām mājās pēc Džūkstes kaujām. Tad tēvs vinu stēepa uz kūtsaugšas zem siena. Nāca tie krievu ǩmmètāji, tikai Dievs izglāba, viņu neatrada. Man pilnīgi jāraud! Tas ir neizsakāmi! Tad viņš Talsos iestājās darbā, bet tomēr kaut kāda nodevība bija, jo vin,u saṇēma ciet un aizsūtīja uz Kirovu.

4. 40.-60. gados dzimušie ir mūsu sabiedrības "pirmā padomju paaudze", kuru audzināšana un skološana notika jau posttotalitārās PSRS laikā un kuriem padomju okupācijas režīms tika normalizēts. Šo cilvēku karjeras veidojās padomju vadoṇu N̦. Hruščova un L. Brežñeva laikā, kad vairums iedzīvotāju Latvijā pieņēma sociālistiskās sistēmas noteikumus un mēǵināja veidot savu dzīvi un karjeru okupētajā Latvijā. Šīs paaudzes naratīvos dominē stāstījumi par padomju laika

37 NMV-4154. 
ikdienu, par šim laikam raksturīgo kolonizācijas un pārkrievošanas politiku, par savstarpējām attiecībām ar līdzcilvēkiem, preču deficītu u. c. Tā 1940. gadā dzimusī Preiḷu ārste Anita Jaunozolina stāsta:

Bija arī tāds laiks, kad pārtika bija tikai uz kartītèm. Veikalos neko nevarēja dabūt, visu tikai pa blatu. Visi dakteru bērni staigāja vienādās drēbēs, jo veikalos to, kas bija palikts zem letes, visi dabüja vienādu. Desu rindās stāvējām veikalā ārā pa durvīm. Tā es vienreiz Preilsos [meitu] Solvitu aizmirsu, stāvot gal̦as veikala rindā. Mani izlaida $\bar{a} r \bar{a}$, lai neredz, ko esmu sapirkusies, pa aizmugures durvīm. Un es, ejot uz mājām, aizgāju uz avīžu kiosku, pieskrēju pie kioska, sametu visas savas desas un kliedzu: "Es aizmirsu bērnu! Es aizmirsu bērnu ratinos!'” Atstāju bērnu ratinos pie veikala parādes durvīm. Tā avī̌̌u pārdeveja visu mūžu to atcerējās. ${ }^{38}$

Raksturīgi, ka šīs paaudzes atmiņas ir visumā fragmentētas un izkaisītas, ko varētu skaidrot ar metanaratīvu trūkumu politiskajā un kultūras atmiṇā par dzīvi stagnācijas laikā. Nereti cilvēki izvēlas arī šim laika posmam "pārlēkt pāri", stāstot par ǵimenes vēsturi pirms š̄ laika vai stāstot par attieksmi pret tiem sociālekonomiskajiem procesiem, kas Latviju skāra 80. gadu beigās un 90. gadu sākumā. Igauṇu pētnieki līdzīgu fenomenu, kad paaudze formējas politisko notikumu vakuumā un kad tās stāsts neatrod savu vietu nacionālajā līmenī, sauc par "kluso paaudzi"39.

5. Nākamā kohorta, ko varētu dēvēt par "atmodas paaudzi", ir 60. gadu beigu 70. gadu sākumā dzimušie. Viņi apzinātā vecumā piedzīvoja gan padomju režīma agoniju, gan neatkarības atjaunošanu. Atmodas procesi - Latvijas Tautas frontes darbība, Baltijas cel̦š, barikādes utt. veido neatñemamu viṇu dzìvesstāstu daḷu.

1968. gadā dzimušais Didzis ${ }^{40}$ stāsta, ka vinam no sākta gala bija skaidrs, ka tas padomju stāsts ir falšs. Es bütībā no bērna kājas esmu bijis antikomunists. Vēlāk es tam piešķīru vārdus, to sev formalizèju. Man ir vienmēr bijis svarīgi nosaukt vārdā lietas, lai

\footnotetext{
38 NMV-4484.

39 Jõesalu 2016.

40 NMV-4490.
}

tās iegūtu tèlu, lai es tās varētu iestrādāt savās dziḷākajās jūtās, būtībā instinktos. Lai varētu darìt tālāk main̄̄gās ikdienas lietas, lai tā ir tā nemainīgā dalı.

No mazām dienām es sapratu, ka tas stāsts, kurā mēs esam ierunāti iekšāa, ir viena lieta, ka tā ir virspuse. Apakšā ir mežabrāḷi, kaut kāda cita pasaule uz polaroìda bildītēm no radiem Kalifornijā. Tur ir kaut kāda Ungārija, kaut kādas burcinas. Ir mūsu lietas, mūsu gurķi, kurus mès paši skābējam, tad pēkšņi kaut kādi mango, bumbieru, kiršu - ungāru konservi, pilnīgi cita pasaule.

Es jau bērnudārzā redzēju, ka pieaugušie dzīvo dubultu dzīvi. Istenībā es vairāk ierakstījos tajā zemes straumē, kur viņi dziedāja kaut kādas nepareizas dziesmas savos svētkos. Es katrā zin̄a bērnībā dabiskāk ieaugu tajā apakšzemes, pretvalstiskajā straumē.

6. Visbeidzot, runājot par 20. gadsimtā radītām paaudzēm, ir 70. gadu beigās 80. gados dzimušie, kas veido pirmo atjaunotās Latvijas Republikas paaudzi. Šo jau pieaugušo cilvēku personību veidošanās process notika jau pēc neatkarības atjaunošanas, un viṇu dzīvesstāstos iepriekšējie procesi tiek tverti pastarpināti - ǵimenes locekḷu vai nacionālo naratīvu iespaidā. Lielā mērā viṇu dzīvesstāstos pastiprināta uzmanība tiek veltīta pašu stāstītāju karjerai un pieredzei, pārdomām par pašreizējām norisēm Latvijā. To var arī saprast, jo šīs paaudzes cilvēki veido ekonomiski aktīvo iedzīvotāju pamatu, viņu dzīves vēl atrodas aktuālo norišu kontekstā, un viniiem vēl nav bijis laika vai vēlēšanās pārdomāt savas dzīves naratīvus, lai tos uzlūkotu par pietiekamiem, paaudzi formējošiem stāstiem.

\section{Nobeigums}

Paaudžu problemātika nenoliedzami ir vēl nepietiekami izmantots resurss Latvijas zinātniskajās aprindās, lai izprastu gan pagātnes, gan arī mūsdienu aktualitātes. Paaudzes formējas tādu pieredžu rezultātā, kas katru paaudzi padara unikālu un nemaldīgu. Pieredzes nevar nodot tieši, tās tiek nodotas ar atmiņas satura starpniecību, kura tiek radīta ar daudz vēlāku naratīvo atlasi, atribūciju, 
interpretācijām utt. Var būt arī mantotas pieredzes, kas pēctečiem tiek nodotas ar nolūku, ar stāstu, novēlētu darbu, institūciju, piemiñas vietu palīdzību. Tomēr nākotnes paaudzes var apzināti vai neapzināti arī šīs pieredzes noliegt, pārinterpretēt vai dzēst ${ }^{41}$. Kā atzīmējusi A. Asmane un L. Šorta, paaudžu nomaina ir vēl viens svarīgs faktors, lai parādītos jaunas sociālas balsis un vīzijas. Ar pāreju no vienas paaudzes uz citu mēs redzam ne tikai publiskās sfēras sardzes nomainu, bet arī novirzes relevances un references rāmjos. Kad vecākās paaudzes pieredze pārceḷas uz sociālu nomali, kḷūstot novecojusi (izñemot vēstures liecinieka ārkārtējo lomu), jaunā paaudze ieņem centrālo vietu, atverot kopējās pieredzes jaunu horizon$t^{42}$. Reflektējot par pagātni, mēs atskatāmies uz iepriekšējām paaudzēm, lūkojot, kā tās ir piepildījušas savu vēsturisko misiju. Mēs varam vērst uzmanību uz to, ko ir vēlējušies nodot attiecīgajā laikmetā dzīvojošie, lai saglabātu savu pieredzi kā liecību, zinot, ka pēcnācēji pēc tā vērtēs vinusus.

Rakstā akcentējām tādu pieeju, kas atškiras no paaudzes apskatīšanas dzimtas kontekstā, kur ǵenealogiiskā jeb gimenes pieeja

\footnotetext{
41 Reulecke 2008.

42 Assmann, Shortt 2012.
}

lielākoties orientējas uz nepārtrauktību, dzīves un tradīcijas atražošanu. Sociāli kulturālā pieeja, kuras ietvaros jau runājam par vēsturiskajām paaudzēm, vairāk uzsver zināmu pārrāvumu sabiedriskajā audumā un pat konfliktu, kur sociālās transformācijas un lūzumi l̦auj iezīmēt noteiktu paaudžu aprises. Tas paver iespēju pētniekiem identificēt, nosaukt, katalogizēt atšķirīgas vecumgrupas jau kā dažādas paaudzes ar savām vēsturiski noteiktajām pazīmēm.

Paaudžu klasifikācija vienmēr atškirirsies gan no pētījuma mērķiem, gan arī izmantoto avotu veida. Mēs mēǵinājām identificēt tās paaudzes, kas no mutvārdu vēstures perspektīvas ir klātesošas kā kolektīvas balsis Latvijas iedzīvotāju individuālajos dzīvesstāstos, viṇu pieredzēs un vērtībās. Ceram, ka diskusija par šāda klasifikācijas modeḷa priekšrocībām vai arī nepiln̄̄bām liks arī citu nozaru pētniekiem izteikt kritiku un konstruktīvus priekšlikumus, pētot Latvijas sociālo vēsturi un aktuālos procesus.

Raksts tapis Latvijas Zinātnes padomes fundamentālo un lietišķo pētījumu projekta Nr. 1zp-2018/1-0458 Atminu pārnese starp paaudzèm: naratīvā perspektīva un LU prioritārā projekta Kritiskā domāšana, inovācija, konkurētspēja un globalizācija ietvaros.

\section{VĒRES}

Aarelaid-Tart, A.; Bennich-Björkman, L. (2011) Baltic Biographies at Historical Crossroads. London : Routledge.

Assman, J. (2013). Das kulturelle Gedächtnis: Schrift, Erinnerung und politische Identität in frühen Hochkulturen. München : C. H. Beck.

Assmann, A.; Shortt, L. (2012) Memory and Political Change. Basingstoke : Palgrave Macmillan.

Attias-Donfutand, C; Arber, S. (2001) Equity and Solidarity across the Generations. Arber, S.; AttiasBurnett, J. Generations: The Time Machine in Theory and Practice. Ashgate.

Bristow, J. (2016) The Sociology of Generations: New Directions and Challenges. London : Palgrave Macmillan.

Caballero, M.; Baigorri A. (2018) Glocalising the theory of generations: The case of Spain. Time \& Society, doi: 10.1177/0961463X18783374 (16.05.2019.).

Corning, A.; Schuman, H. (2015) Generations and Collective Memory. Chicago, IL : University of Chicago Press.

Donfut, C. The Myth of Generational Conflict: The Family and State in Ageing Societies. London : Routledge.

Edmunds, J.; Turner, B. S. (2002) Generations, Culture and Society. Buckingham : Open University Press. 
Frei, N. (2009) Deutsche Lernprozesse: NS-Vergangenheit und Generationenfolge seit 1945. Frei, N. 1945 und wir: Das Dritte Reich im Bewußtsein der Deutschen. München : Deutscher Tachenbuch.

Fulbrook, M. (2011) Dissonant Lives: Generations and Violence through the German Dictatorships. Oxford : Oxford University Press.

Goltz, A. (2011) Generations of 68ers: Age Related Constructions of Identity and Germany's '1968'. Cultural and Social History, 8, 4, 473-490.

Gudule, L.; Pētersons, E. (2012) Latvijas paaudžu anatomija. Pieejams: www.slideshare.net/DDBLatvia/ paaudu-anatomija (15.06.2019.).

Hobsbawm, E. (1995) Age of Extremes: The Short Twentieth Century 1914-1991. London : Abacus.

Jõesalu, K. (2016) We were the children of a romantic era: nostalgia and the nonideological everyday through the perspective of a 'Silent Generation'. Journal of Baltic Studies, 47, 4, 557-577.

Kaprāns, M.; Procevska O. (2013) Latvijas sociālās atmiņas monitorings: Ziņojums Nr. 1. Rīga. Pieejams: oldweb.km.lv/lv/doc/jaunumi/jaunumi_2013/socialas_atminas_monitorings.pdf_(15.06.2019.).

Kaprāns, M.; Saulītis A. (2017) Latvijas sociālās atmiṇas monitorings: Ziņojums Nr. 2. Rīga. Pieejams: www.academia.edu/32932266/Latvijas_sociālās_atminas_monitorings_2017 (15.06.2019.).

Koroḷeva, I.; Mieriṇa, I.; Rungule, R. (2014) Profesiju prestižs un izvēele jauniešu vidū: divu paaudžu salīdzinājums. Rīga : LU Akadēmiskais apgāds.

Levada, Ju. (2011) Pokolenija XX veka: vozmožnosti issledovanija. Levada, Ju. Sočinenija: Problema čeloveka. Moskva: Karpov.

Lorencs, J. (2019) Kas bijām mēs - paaudze, kas atguva Latvijas neatkarību? Latvijas Avīze (04.05.2019.).

Mannheim, K. ([1952] 1997) The problem of generations. Collected Works of Karl Mannheim, 5. London : Routledge, 276-320.

Matīsa, K (2019) Filmas "Kaza kāpa debesīs" recenzija. Brīvā gara reputācija. Diena (13.04.2019.).

Nugin, R.; Kannike, A.; Raudsepp, M. (2016) Generations in Estonia: Contemporary Perspectives on Turbulent Times. Approaches to Culture Theory, 5. Tartu : University of Tartu Press.

Palmberger, M. (2016) How Generations Remember: Conflicting Histories and Shared Memories in PostWar Bosnia-and-Herzegovina. London : Palgrave Macmillan.

Reulecke, J. (2008) Generation/Generationality, Generativity, and Memory. Erlland, A.; Nünning, A.; Young, S. B. (eds.) Cultural Memory Studies: An International and Interdisciplinary Handbook. Berlin : Walter de Gruyter.

Saliniece, I. (2015) Toreiz un tagad: Latvijas vēstures "smagie" notikumi mūsdienu uztverē. Stašulāne, I. (red.) Kultūras studijas: Zinātnisko rakstu krājums, VII: Vēsturiskā atmiņa. Daugavpils : DU akadēmiskais apgāds "Saule", 7-45.

Sayner, J. (2007) Women without a Past?: German Autobiographical Writings and Fascism. Amsterdam, NY : Rodopi.

Strauss, W.; Howe, N. (1991) Generations: The History of America's Future, 1584-2069. New York : Quill William Morrow.

Thomson, A. (2016) Australian Generations?: Memory, Oral History and Generational Identity in Postwar Australia. Australian Historical Studies, 47, 1, 41-57.

Vails, P.; Genis, A. (2006) 60. gadi. Padomju cilvēka pasaule. Rīga : Jumava.

Valpēters, E. (sast.) (2010) Nenocenzētie. Alternatīvā kultūra Latvijā. XX gs. 60-tie un 70-tie gadi. Rīga : Latvijas Vēstnesis.

Voronkov, V. M. (2005) Proekt «šestidesatnikov». Levada, Ju. (sast.) Otcy i deti: Pokolenčeskij analiz sovremennoj Rosii. Moskva : Novoe literaturnoe obozrenie.

Wangler, A. (2012) Rethinking History, Reframing Identity: Memory, Generations, and the Dynamics of National Identity in Poland. Heidelberg : Springer VS.

Žilinskienė, L.; Ilic, M. (2018) Changing family values across the generations in twentieth-century Lithuania. Contemporary Social Science, doi: 10.1080/21582041.2018.1516297 (12.07.2019.). 